\title{
Some observations from radiometric ' 8 bit' data of sediment thin sections based on alternative petrographic image analysis method
}

\author{
Sudip Dey ${ }^{1, *}$, Suvendu Ghosh ${ }^{1}$, Chandrani Debbarma $^{1}$, Prasamita Sarkar ${ }^{1}$, \\ Mhu Aris MarFaI ${ }^{2,3, * *}$ and Sabyasachi Maiti ${ }^{4, \dagger}$ \\ ${ }^{1}$ Department of Geography and Disaster Management, Tripura University, \\ Suryamaninagar 799 130, Tripura, India. \\ 2 Institute of Geography, Justus-Liebig-University, 35390 Giessen, Germany \\ ${ }^{3}$ Geography Faculty, Gadjah Mada University, 55281 Yogyakarta, Indonesia. \\ ${ }^{4}$ Department of Geology and Geophysics, Indian Institute of Technology, Kharagpur, India. \\ *e-mail: sudip_geo@rediffmail.com \\ **e-mail: Muh.Marfai@geogr.uni-giessen.de \\ †e-mail: maiti@gg.iitkgp.ernet.in
}

This paper deals with the experiment of sediment microstructure analysis especially microfabric mapping by digital imaging. For that purpose the greyscale images (Red band from RGB combination) of the thin sections have been prepared from the selected 12 samples. The basis of this mapping is the reflectance capacity of different sediments which is influenced by the physical parameters like grain size and colour. The reflectances of different sediments are represented in digital format by different $\mathrm{DN}$ values from 0-255 within the radiometric ranges of ' 8 bit' data. Density slicing has been chosen as the method of microstructure mapping in this research. This study shows that lower DN values normally present dark coloured coarser sand and clay while higher DN values present light coloured finer sediment samples. In the selected samples for this study the maximum DN value has been found from micaceous materials. Another remarkable thing observed from the microfabric mapping is that the presence of coarser sediments forms complex microfabric pattern than the finer sediments in the study area. Though this method have some demerits, still its simple technique can be very useful for accurate microstructure analysis.

\section{Introduction}

Microstructure study of sedimentary rocks is considered as a scientifically fascinating subject of profound practical importance (Radlinski et al 2005). Presently scientific studies on rock microstructure are directed towards two focal objectives, firstly to understand the environment and genesis of rocks and secondly to understand the forms (microarchitecture) and distribution patterns of minerals (microfabric). In the mid $70 \mathrm{~s}$ of the last century, Brewer (1976) studied soil fabric at micro level which was very remarkable for the initial growth of systematic microfabric studies. From the early 80s, methodological approaches in microstructure study have become more experimental. Inventions of sophisticated scientific tools during that period played an important role behind many confident experimental works in microarchitecture and microfabric analysis. Uses of SEM and optical microscopy, molecular adsorption, SAXS and SANS resulted massive

Keywords. Microstructure; sediment layers; digital number; reflectance; coverage analysis. 
development in microstructure research and petrographic image analysis (PIA) which was reflected by the works of Bale and Schmidt (1984); Katz and Thompson (1985); Wong et al (1986); Jacquin and Adler (1987) and Hansen and Skjeltrop (1988). Apart from those, some contemporary works by van der Meer (1987, 1993, 1996); van der Meer and Laban (1990); Menzies and Maltman (1992) concentrated on the various evidences of genesis and deformation. Over the last two decades, particularly from the middle of 90s, the method of digital microphotography has become very popular in sedimentological studies. Bryant and Davidson (1996) attempted a micromorphological study by image analysis on old cultivated soils. Later, Cooper (1998) also observed the usefulness of digital image analysis in sediment studies. Studies by Lachniet et al (1999, 2001) discussed the complex impact of process on microstructure development. Vernon (2004) presented a general outline on practical approach of igneous, sedimentary and metamorphic rock microstructure. Meanwhile some experiments on sediment thin section made by Cocquyt and Israe (2004) and Rohrig and Scharf (2006) resulted remarkable advancement in sediment microstructure research. A very recent work by Mamtani et al (2007) deals with the geometric forms and depositional nature of BIF (Banded Iron Formation) by high resolution microphotography. In the same year another remarkable study was done by Cashman et al (2007) on microstructure development by tectonic events in near surface sediments.

Considering the recent trends, we decided to perform an experiment on microstructure study of sedimentary thin sections. The basic objective of this study concentrates on the methodological approach to digital imaging of sediment thin sections and microstructure analysis on the basis of the reflectance of different minerals in ' 8 bit' radiometry.

\section{Methods and materials}

\subsection{The study area}

For the present study some samples of sedimentary rocks were collected from a part of the eastern margin of the lateritic area of Medinipur district (figure 1). According to the classification of tectonic provinces of Bengal basin by Alam et al (2003), this study area falls in a part of passive to extensional cratonic margin in the west of Bengal basin or the western geotectonic province. Niyogi (1970) and Pal (2002) have already identified this place as a part paleo-coastal zone of Bengal basin. It has been widely attributed by some early researchers that geologically entire Bengal basin is a large composite basin with a varied tectonic history (Uddin and Lundberg 1998, 2004). Works by Umitsu (1987); Bera (1996); Hazra et al (2001); Dey (2002); Dey et al (2002), etc., show that the Quaternary period landform development in Bengal basin was influenced by several phase of sea transgressions each followed by regressions. In the selected study area, different structural patterns of sedimentary bedding like plane bedding, graded bedding, antidunes, wave ripples, and cross beddings have been observed in different depths (table 1) which preserve the early changes of geomorphic processes and environmental succession. Moreover, a wide range of variations in grain sizes also has been recognised in those different sediment depositions. The attractive history of environmental dynamics through Tertiary and Quaternary periods and present structure played an important role to draw the attention for selecting this area for sampling and conducting a study.

\subsection{Thin section making and imaging}

During the field work, a total of 50 rock samples were collected (10 from each structure) among which 12 samples were finally selected for microphotography on the basis of structural assemblage and grain sizes (table 2). Some very common materials like a small tile saw, an electric warming plate, glass stick, petrographic glass slides, etc., were used for preparing thin sections in the laboratory. A coating of liquid wax mixed with transparent synthetic gum was used for cutting and making the primary blocks from very soft or easily breakable sediment samples under wet condition. An electric warmer was used for drying the samples in very mild temperature $\left(25^{\circ} \mathrm{C}\right)$ and then finally those were prepared for sectioning. Again epoxy and hardener were used in 2:1 ratio before making the thin sections. An ordinary sharp edged small stainless steel knife blade was used for making sections and removing the coating from those sediment layers. Actually one perfect flat surface of each $30 \mu \mathrm{m}$ thick sections was needed for this experiment to use the sections as objects of reflectance or 'reflectors' in this experiment. The size of the thin sections was restricted in $20 \mathrm{~mm} \times 15 \mathrm{~mm}$ because it was very difficult to make larger sections with the soft sediment layers. Microphotography was done by microscopic ( $15 \times$ eye pieces and $40 \times$ objective lance), halogen light $6 \mathrm{~V}, 20 \mathrm{~W}$ bulb (reflection light) and fixed high resolution digital camera (8.5 megapixel). The resolution of the images was fixed at $100 \mu \mathrm{m}$ in the same magnification. Finally digital datasets or images were enhanced and zoomed up to pixel level manually in computer and analysed by 


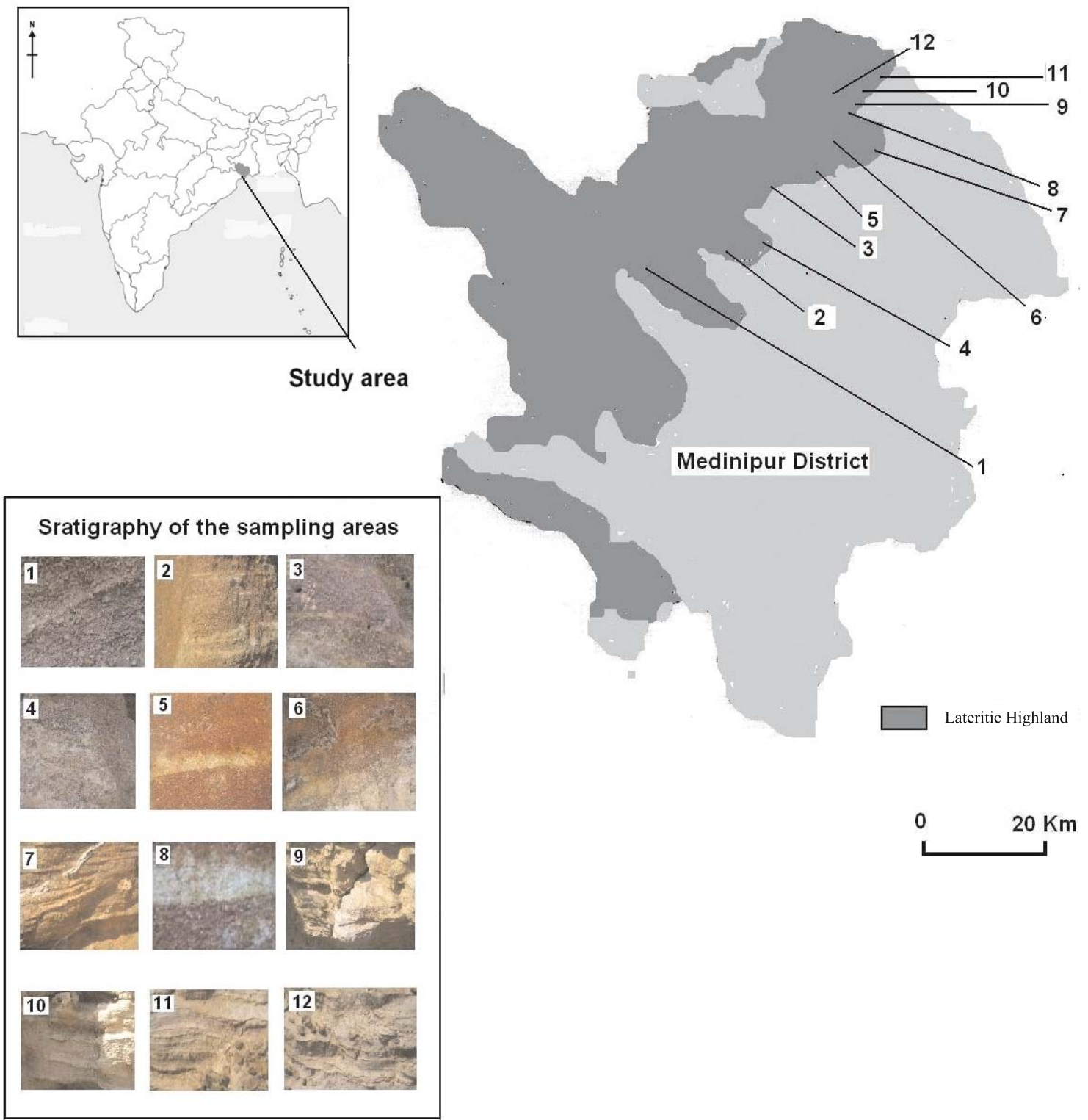

Figure 1. Location of sampling areas and main sediment beddings observed in that place.

Table 1. Sediment beddings and sediment characters in selected area of sampling.

\begin{tabular}{lclc}
\hline $\begin{array}{l}\text { Sediment bedding (from } \\
\text { upper to lower succession) }\end{array}$ & $\begin{array}{c}\text { Depth } \\
\text { from the } \\
\text { surface }\end{array}$ & $\begin{array}{c}\text { Types of dominating } \\
\text { deposition }\end{array}$ & Grain size \\
\hline Conglomerate plane bedding & $0 \mathrm{~m}$ & Gravels \\
Graded bedding & $2-5 \mathrm{~m}$ & Coarse sand to fine \\
& & gravels & $16000-64000 \mu \mathrm{m}$ \\
Graded bedding (flame structure) & $2-5 \mathrm{~m}$ & Silt and loamy sand & $7.22-30 \mu \mathrm{m}$ and \\
Antidunes & $3-5 \mathrm{~m}$ & & $250-500 \mu \mathrm{m}$ \\
Trough cross bedding & $4-7 \mathrm{~m}$ & & \\
Plane bedding (silt) & $4-8 \mathrm{~m}$ & & \\
Cross bedding & $7-9 \mathrm{~m}$ & & \\
Wave ripples (asymmetrical) & $9-10 \mathrm{~m}$ & Coarse silt & $15.53-62.52 \mu \mathrm{m}$ \\
Symmetrical ripples & $9-10 \mathrm{~m}$ & Silty clay & $3.09-0.97 \mu \mathrm{m}$ \\
\hline
\end{tabular}


Table 2. Samples for digital image analysis.

\begin{tabular}{|c|c|c|c|c|}
\hline $\begin{array}{c}\text { Sample } \\
\text { no. }\end{array}$ & Types of depositions & $\begin{array}{c}\text { Mineral } \\
\text { composition }\end{array}$ & Grain size & $\begin{array}{l}\text { Structure of the } \\
\text { sampling point }\end{array}$ \\
\hline 1 & $\begin{array}{l}\text { Very coarse sand } \\
\text { Coarse sand } \\
\text { Silt }\end{array}$ & $\begin{array}{l}\text { Micaceous } \\
\text { Siliceous } \\
\text { Siliceous }\end{array}$ & $\begin{array}{l}1500-2500 \mu \mathrm{m} \\
700-1000 \mu \mathrm{m} \\
7.22-30 \mu \mathrm{m}\end{array}$ & Graded bedding \\
\hline 2 & $\begin{array}{l}\text { Coarse sand } \\
\text { Loamy sand } \\
\text { Silt }\end{array}$ & $\begin{array}{l}\text { Siliceous } \\
\text { Siliceous } \\
\text { Siliceous }\end{array}$ & $\begin{array}{l}700-1000 \mu \mathrm{m} \\
250-500 \mu \mathrm{m} \\
7.22-30 \mu \mathrm{m}\end{array}$ & $\begin{array}{l}\text { Graded bedding } \\
\quad \text { (flame shaped) }\end{array}$ \\
\hline 3 & $\begin{array}{l}\text { Very coarse sand } \\
\text { Loamy sand } \\
\text { Silt }\end{array}$ & $\begin{array}{l}\text { Micaceous } \\
\text { Siliceous } \\
\text { Siliceous }\end{array}$ & $\begin{array}{l}1500-2500 \mu \mathrm{m} \\
250-500 \mu \mathrm{m} \\
7.22-30 \mu \mathrm{m}\end{array}$ & Graded bedding \\
\hline 4 & $\begin{array}{l}\text { Coarse sand } \\
\text { Loamy sand } \\
\text { Silt }\end{array}$ & $\begin{array}{l}\text { Siliceous } \\
\text { Siliceous } \\
\text { Siliceous }\end{array}$ & $\begin{array}{l}700-1000 \mu \mathrm{m} \\
250-500 \mu \mathrm{m} \\
7.22-30 \mu \mathrm{m}\end{array}$ & Graded bedding \\
\hline 5 & $\begin{array}{l}\text { Very coarse sand } \\
\text { Coarse sand } \\
\text { Loamy sand } \\
\text { Silt }\end{array}$ & $\begin{array}{l}\text { Siliceous } \\
\text { Siliceous } \\
\text { Siliceous } \\
\text { Siliceous }\end{array}$ & $\begin{array}{l}1000-2500 \mu \mathrm{m} \\
700-1000 \mu \mathrm{m} \\
250-500 \mu \mathrm{m} \\
7.22-30 \mu \mathrm{m}\end{array}$ & $\begin{array}{l}\text { Graded bedding } \\
\quad \text { (flame shaped) }\end{array}$ \\
\hline 6 & $\begin{array}{l}\text { Very coarse sand } \\
\text { Coarse sand } \\
\text { Silt }\end{array}$ & $\begin{array}{l}\text { Micaceous } \\
\text { Siliceous } \\
\text { Siliceous }\end{array}$ & $\begin{array}{l}1500-2500 \mu \mathrm{m} \\
700-1000 \mu \mathrm{m} \\
7.22-30 \mu \mathrm{m}\end{array}$ & Graded bedding \\
\hline 7 & $\begin{array}{l}\text { Loamy sand } \\
\text { Coarse silt } \\
\text { Silt } \\
\text { Silty clay }\end{array}$ & $\begin{array}{l}\text { Siliceous } \\
\text { Siliceous } \\
\text { Siliceous } \\
\text { Siliceous }\end{array}$ & $\begin{array}{l}250-500 \mu \mathrm{m} \\
15.53-62.52 \mu \mathrm{m} \\
7.22-30 \mu \mathrm{m} \\
0.97-3.09 \mu \mathrm{m}\end{array}$ & Cross bedding \\
\hline 8 & $\begin{array}{l}\text { Very coarse sand } \\
\text { Coarse sand } \\
\text { Loamy sand } \\
\text { Silt }\end{array}$ & $\begin{array}{l}\text { Siliceous } \\
\text { Siliceous } \\
\text { Siliceous } \\
\text { Siliceous }\end{array}$ & $\begin{array}{l}1000-2500 \mu \mathrm{m} \\
700-1000 \mu \mathrm{m} \\
250-500 \mu \mathrm{m} \\
7.22-30 \mu \mathrm{m}\end{array}$ & $\begin{array}{l}\text { Graded bedding } \\
\quad \text { (flame shaped) }\end{array}$ \\
\hline 9 & $\begin{array}{l}\text { Loamy sand } \\
\text { Silt } \\
\text { Silty clay }\end{array}$ & $\begin{array}{l}\text { Siliceous } \\
\text { Siliceous } \\
\text { Siliceous }\end{array}$ & $\begin{array}{l}250-500 \mu \mathrm{m} \\
7.22-30 \mu \mathrm{m} \\
0.97-3.09 \mu \mathrm{m}\end{array}$ & Plane bedding \\
\hline 10 & $\begin{array}{l}\text { Coarse sand } \\
\text { Loamy sand } \\
\text { Silt }\end{array}$ & $\begin{array}{l}\text { Siliceous } \\
\text { Siliceous } \\
\text { Siliceous }\end{array}$ & $\begin{array}{l}700-1000 \mu \mathrm{m} \\
250-500 \mu \mathrm{m} \\
7.22-30 \mu \mathrm{m}\end{array}$ & Plane bedding \\
\hline 11 & $\begin{array}{l}\text { Silt } \\
\text { Silty clay }\end{array}$ & $\begin{array}{l}\text { Siliceous } \\
\text { Siliceous }\end{array}$ & $\begin{array}{l}7.22-30 \mu \mathrm{m} \\
0.97-3.09 \mu \mathrm{m}\end{array}$ & Symmetrical ripples \\
\hline 12 & $\begin{array}{l}\text { Coarse silt } \\
\text { Loamy sand } \\
\text { Silt }\end{array}$ & $\begin{array}{l}\text { Siliceous } \\
\text { Siliceous } \\
\text { Siliceous }\end{array}$ & $\begin{array}{l}15.53-62.52 \mu \mathrm{m} \\
250-500 \mu \mathrm{m} \\
7.22-30 \mu \mathrm{m}\end{array}$ & Wave ripples \\
\hline
\end{tabular}

microstructure analysing software like LSM Image Browser. Minerals and their geometry (shape, size and surface conditions) were identified by LSM Image Bowser. For classification of different DN groups we used ILWIS 3.3 image processing software which is normally used for remote sensing (figure 2). In that remote sensing software we imported the images after enhancing and zooming which were ten times larger than their original size and well visible as raster data.

\subsection{Dataset}

In this study, an attempt was made to analyse microstructure at radiometric level. Single band or grayscale images were used for microstructure analysis because the single band data allows computing of each pixel (digital number) and selective gray level threshold. Though it is a fact that today colour images provide many information in scientific studies, a recent work by Dey et al (2009) used 


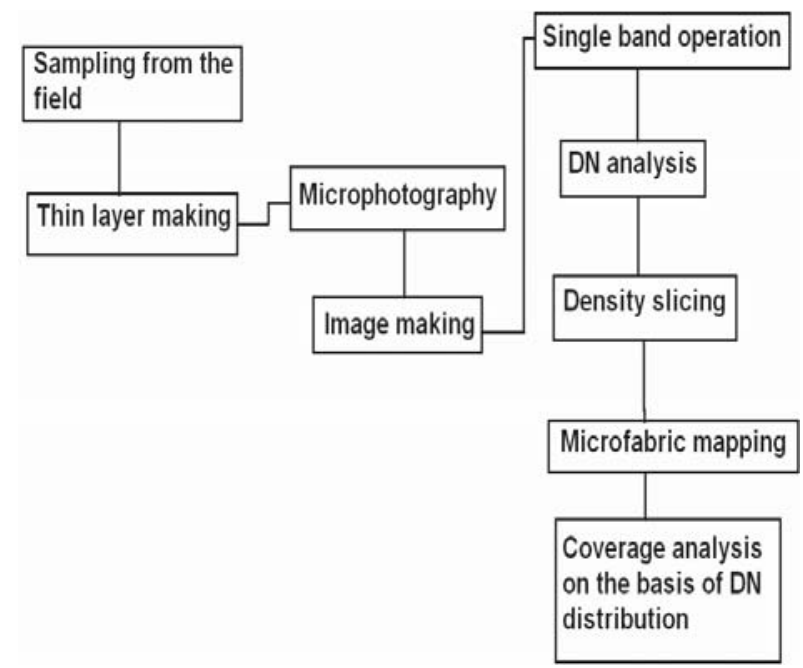

Figure 2. Flowchart of digital operation. the single band images for microstructure analysis which advocates that single band images are very useful for in assessing many physical characteristics especially the surface conditions even at micro level. Recently some physicists are using some specific software (WXsM 4.0 for example) for micro and nanomorphology analysis from mono-spectral images based on 'Black Body' concept. Normally two very popular uses of greyscale images in scientific works are in medical science and in remote sensing. In Earth System Science, greyscale images are used very popularly for analysing geomorphic and geological features in remote sensing application. Whithe and El Asmar (1999) introduced an algorithm function for DN analysis while Frazier and Page (2000), Yanli (2002), Marfai (2003), Bagli and Soille (2003) and Chalabi et al (2006)
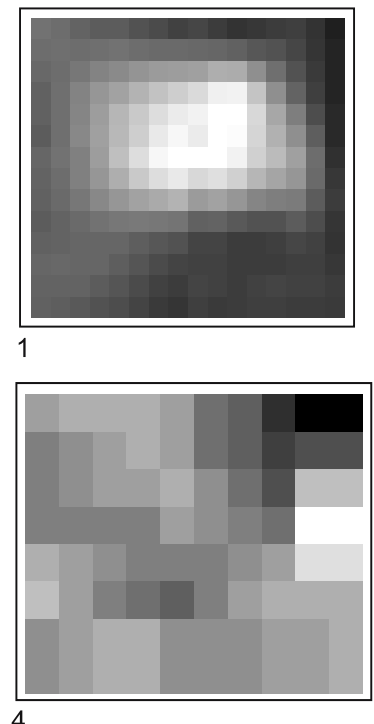

4
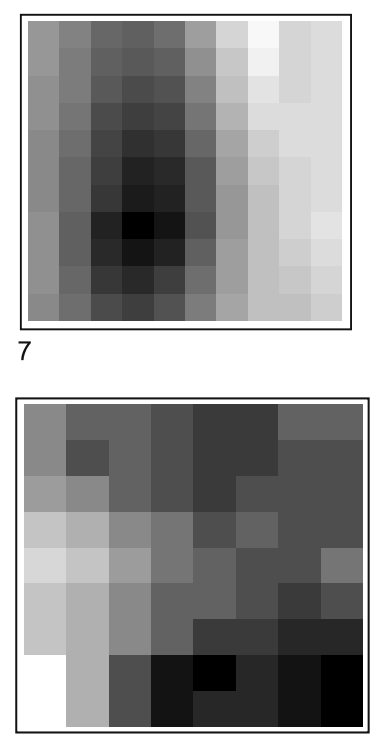

10
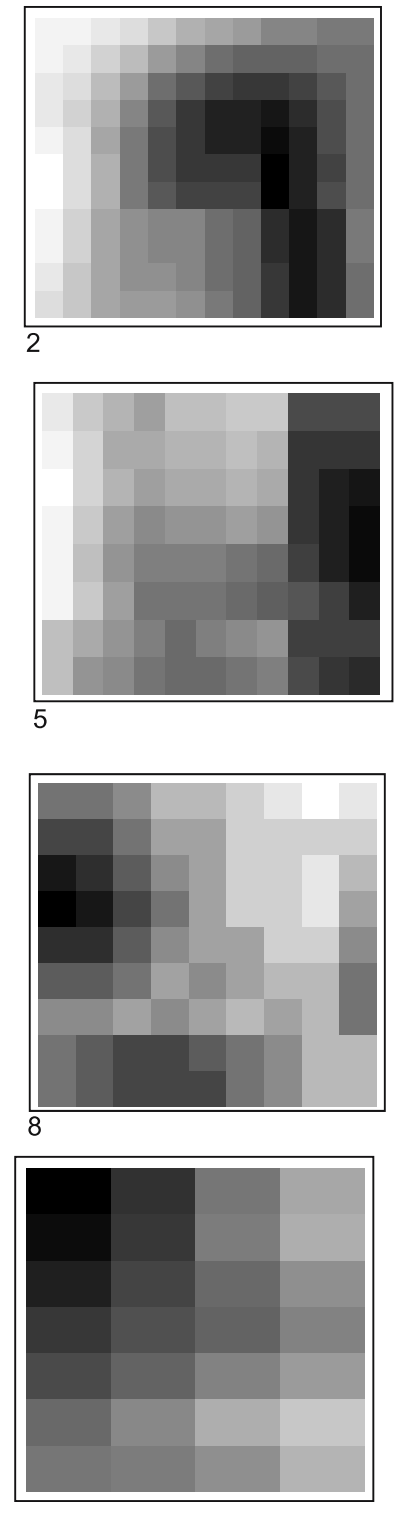

11
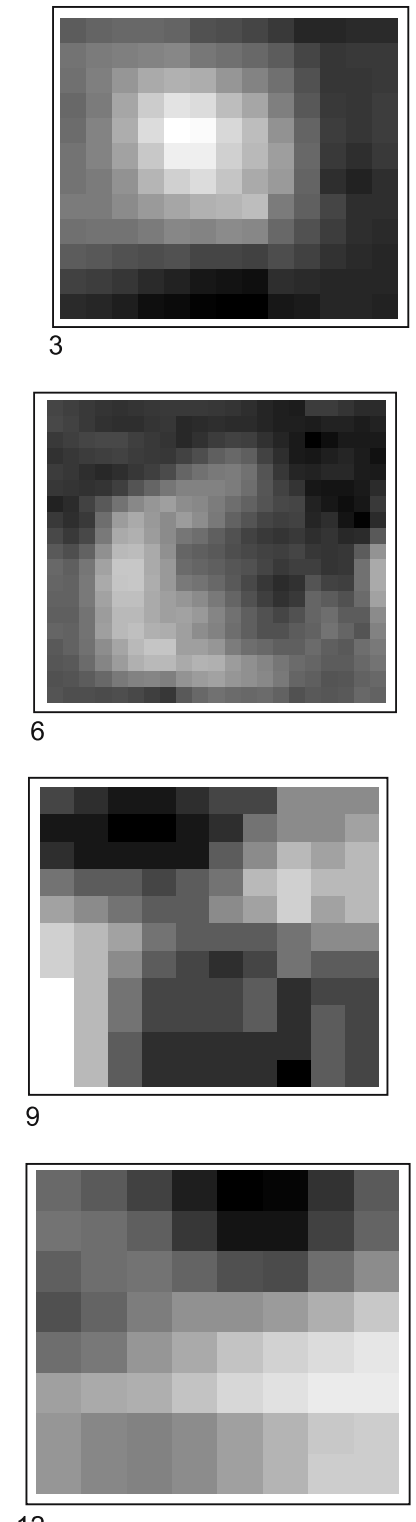

12

Figure 3. Digital dataset of the sediment layer samples (12 finally selected samples). 
Table 3. Coverage area (in percentage) of the sediments.

\begin{tabular}{|c|c|c|c|c|c|c|c|}
\hline \multirow[b]{2}{*}{$\begin{array}{l}\text { Sample } \\
\text { no. }\end{array}$} & \multicolumn{7}{|c|}{ Coverage area in percentage } \\
\hline & $\begin{array}{l}\text { Very coarse } \\
\text { sand }\end{array}$ & $\begin{array}{l}\text { Coarse } \\
\text { sand }\end{array}$ & $\begin{array}{l}\text { Loamy } \\
\text { sand }\end{array}$ & $\begin{array}{l}\text { Coarse } \\
\text { silt }\end{array}$ & Silt & $\begin{array}{l}\text { Silty } \\
\text { clay }\end{array}$ & Micacious \\
\hline 1 & - & 50 & - & - & 24 & - & 26 \\
\hline 2 & - & 25 & 50 & - & 25 & - & - \\
\hline 3 & - & - & 48 & - & 23 & - & 29 \\
\hline 4 & - & 37 & 15 & - & 48 & - & - \\
\hline 5 & 25 & 24 & 25 & - & 26 & - & - \\
\hline 6 & - & 50 & - & - & 25 & - & 25 \\
\hline 7 & - & - & - & 49 & 21 & 30 & - \\
\hline 8 & - & - & 49 & - & 35 & 16 & - \\
\hline 9 & - & - & - & - & 34 & 66 & - \\
\hline 10 & - & 31 & 23 & - & 46 & - & - \\
\hline 11 & - & - & - & - & 49 & 51 & - \\
\hline 12 & - & 23 & - & - & 50 & 27 & - \\
\hline
\end{tabular}

experimented on different greyscale resolution analysing the physical features. Recently Marfai et al (2008) successfully used greyscale images for the detection of shoreline changes. Use of high resolution grayscale or single band images by Dey et al (2008) for the assessment of microgeomorphic or very small features of landform proves that greyscale images are suitable for the analysis of physical characters of small sedimentary features at micro level.

In the present study the basics of remote sensing image processing methods were applied for microstructure image analysis according to the need of the research. Red band within total of R-G-B scheme of the digital datasets was chosen for its better contrast and higher reflectance value to differentiate grains (figure 3). Displayed images of 8-bit data are typically composed of shades of gray, varying from black $(\mathrm{DN}$ value $=0)$ at the weakest reflection to white $(\mathrm{DN}$ value $=255)$ at the strongest.

\subsection{Microfabric mapping}

One of the main objectives of this study is microfabric mapping for understanding the patterns of depositions. For that purpose we adopted density slicing method. In this method operation is done by dividing the range of brightness in a single band into intervals and assigning each interval to a class for final mapping. Here, a total of six types of grain classes are found within the selected samples which represent different DN value ranges. Measured digital numbers of each type of grains in different samples are used for making interval classes and then assigned in the maps. The mapping based on the pattern of $\mathrm{DN}$ distribution has been directed towards the analysis of microfabric patterns and percentage of coverage area of DN classes corresponding different microstructural combination in the digital map.

To understand the sediment characteristics, the percentage of sediment coverage is considered very important. Here the surface/coverage is measured by the number of pixels representing different type of grain classes in the samples (table 3). The following simple mathematical explanation is suitable for measuring the area coverage:

$$
A=\frac{100 \times P}{P_{N}}
$$

where, $A$ is the percentage of area coverage, $P$ is the number of pixels in particular class (sediment) and $P_{N}$ is the total number of pixels in images.

\section{Results and discussions}

\subsection{Significance of digital number distribution in the images}

The present study shows that structural combinations, grain pattern and colour influence on the distribution of digital number values of the images of sediment sections (figure 4). From the prepared datasets, we found that coarser grains have lesser DN values than that of the finer ones due to their darker colours and rough surface. Light coloured and fine grained silt $(30-7.22 \mu \mathrm{m})$ is represented 

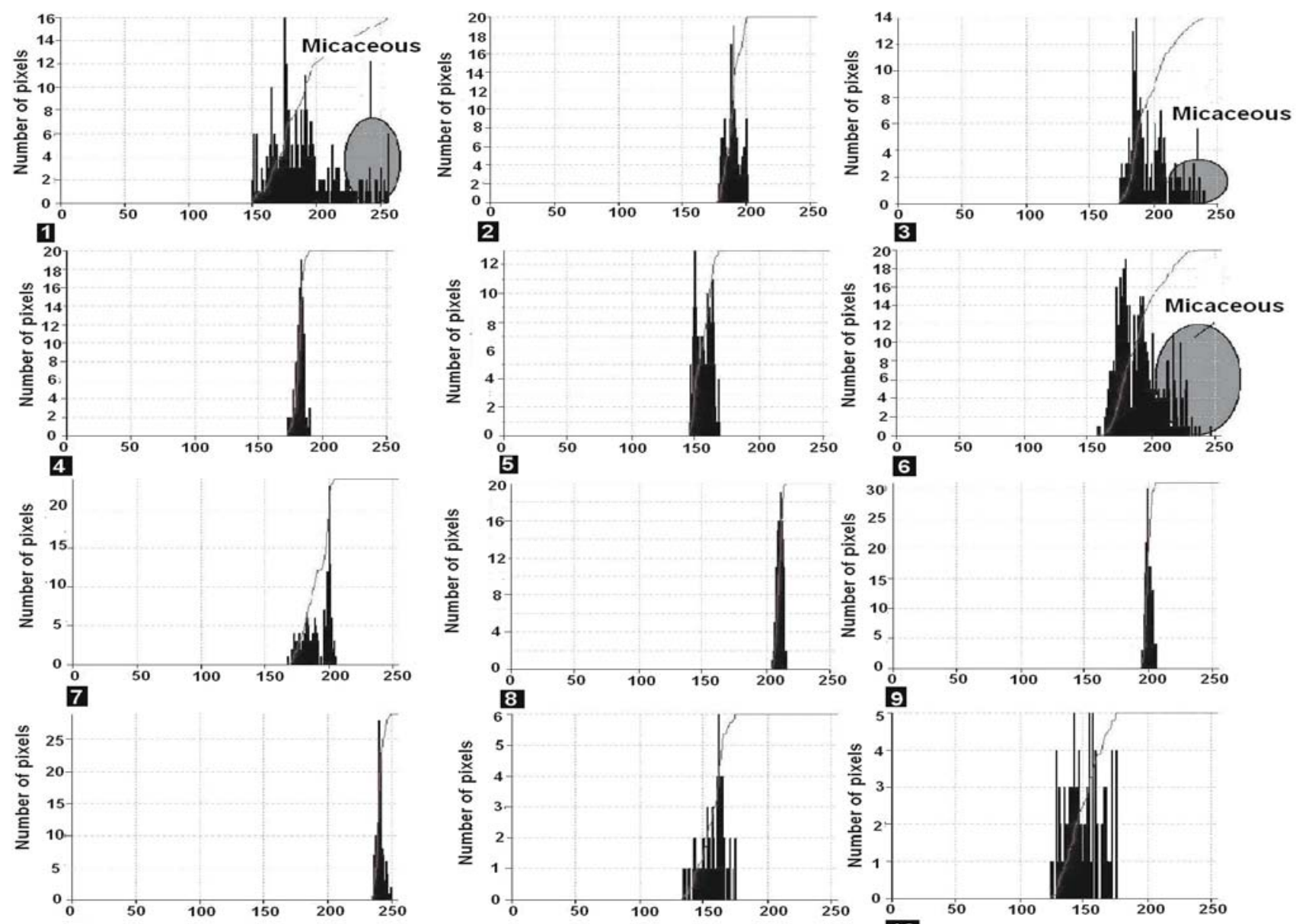

10
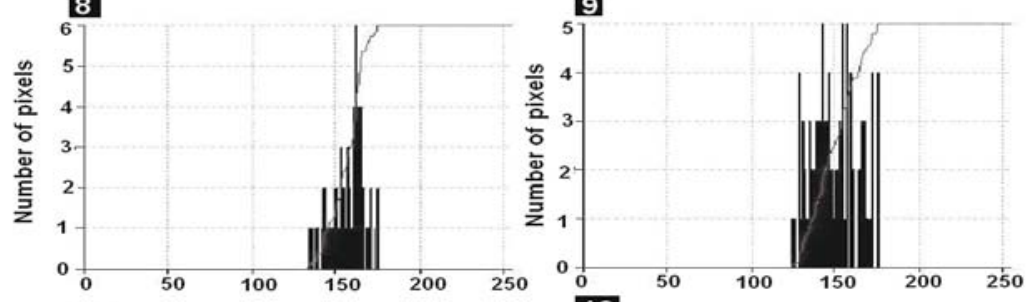

Figure 4. Digital number distribution of the 12 digital dataset.

by higher value of digital numbers for its near perfect reflection. On the other hand, silty clay layers have low reflectance due to the presence of clay, which is dark in colour. Some compositions like micaceous are represented by highest DN value (maximum 255) because of its glittering and whitish colour with smooth surface which result high level reflection.

\subsection{Microfabric patterns}

From the digital number mapping of 12 sediment samples (figure 5), a significant difference in microfabric patterns is observed. The coarser grained depositions have complicated microfabric patterns than the finer sediments. Very coarse particles of micaceous play an important role to form nucleated pattern (sample 1, sample 3 and sample 6). Sample 2 shows arranged pattern in which coarse and loamy sands are injected in the finer silts. Samples 4,5 and 10 are represented by unarranged patterns in which coarse and loamy sands are deposited along with fine grained silt. Finer depositions like silt, clay, etc., represent comparatively simple and arranged pattern. Samples 7, 9, 11 and 12 , are the good examples of this pattern. In the samples 8 and 12 , some complex patterns are found due to the presence of some coarser grained sands.

\subsection{Coverage analysis}

Among the tested samples, samples 1, 2, 3, 4, 5 and 6 are formed by mainly coarser grain sizes which covers more than $50 \%$ of the thin layers. For example, in sample 1, coarse sand and micaceous are covering about $77 \%$ and the rest is covered by silt. Two other samples like 3 and 6 also have almost same microstructural type which indicate similar or nearly similar environments of deposition. Samples 2 and 5 also show the domination of greater grain size. It is indicated that they were deposited under the similar environmental conditions like samples 1,3 and 6 . Here sample 5 shows a little difference as coarse and fine grains recorded is nearly equal amount in this sample. This might be due to little stabilisation of the environmental condition during the deposition. 
Domination of finer sediments is found in the samples of $7,8,9,10,11$ and 12 . The physical properties of these samples are also recorded different from the previous six samples. These are darker in colour and finer in character due to the presence of silt and clay. Sample 11 consists of silt
(49\%) and clay (51\%), is a good example of this type of deposition. Sample 7 can be considered as another good example of the same category which consists of coarse silt (49\%), silt (20\%) and clay (31\%). The other samples like 8, 9, 10 and 12 show either $>50 \%$ or nearly $50 \%$ coverage of finer
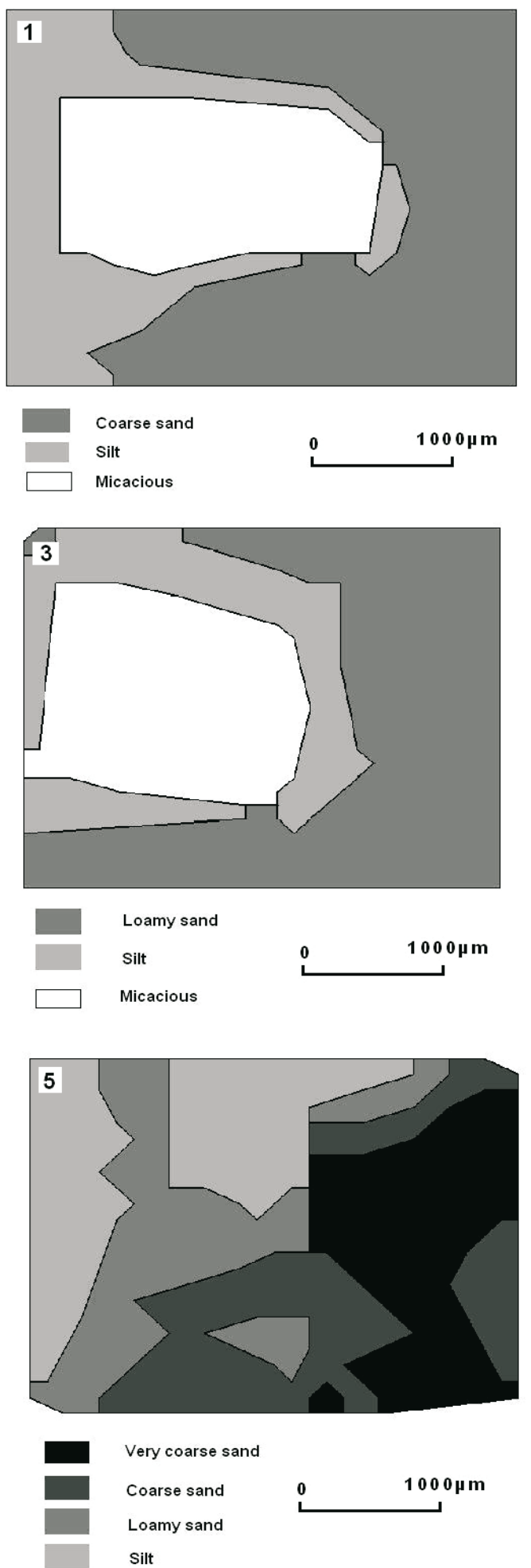
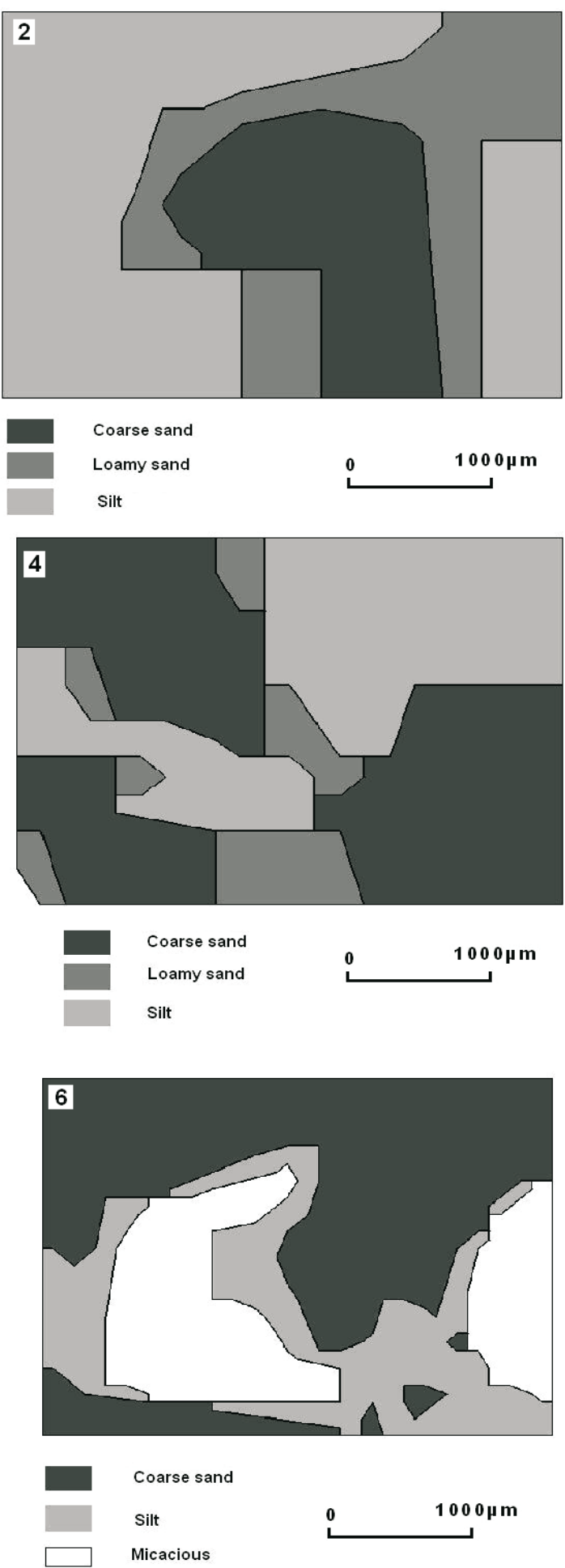

Figure 5. Microfabric maps prepared by density slicing method. 

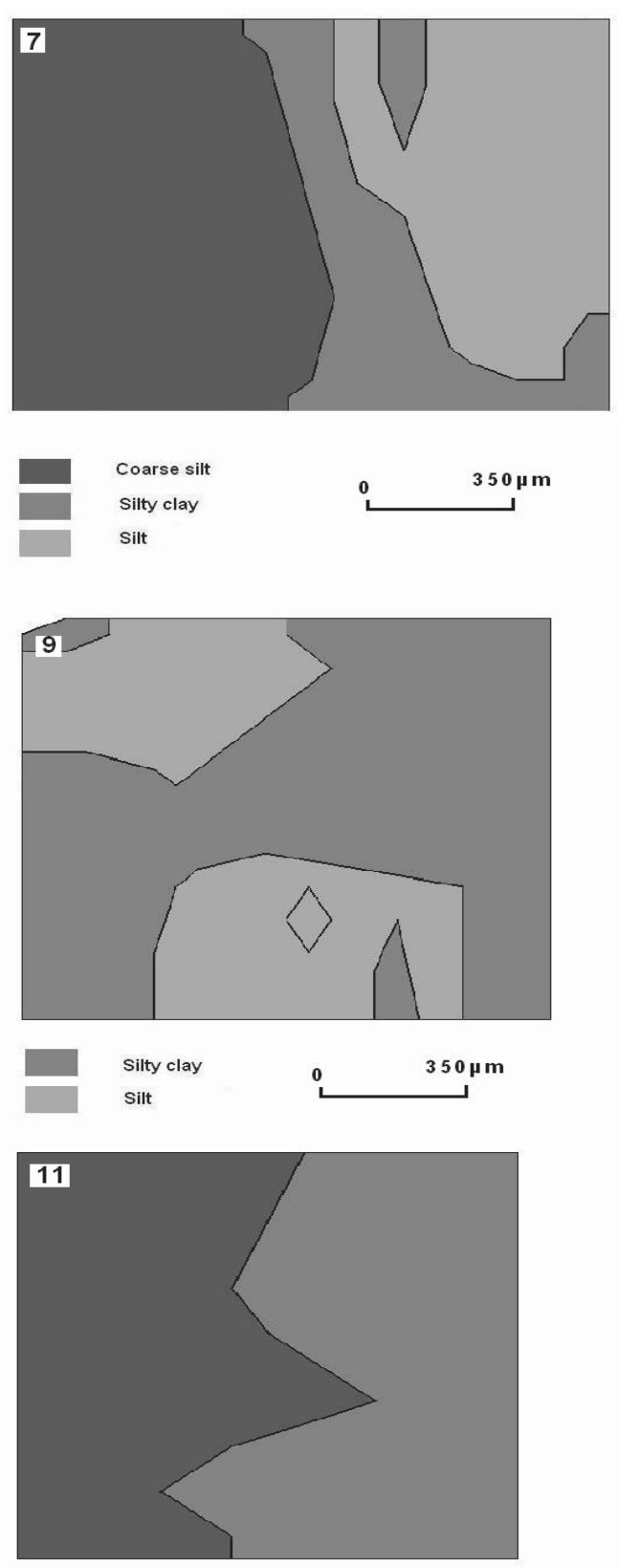

Silty clay

Silt

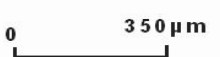

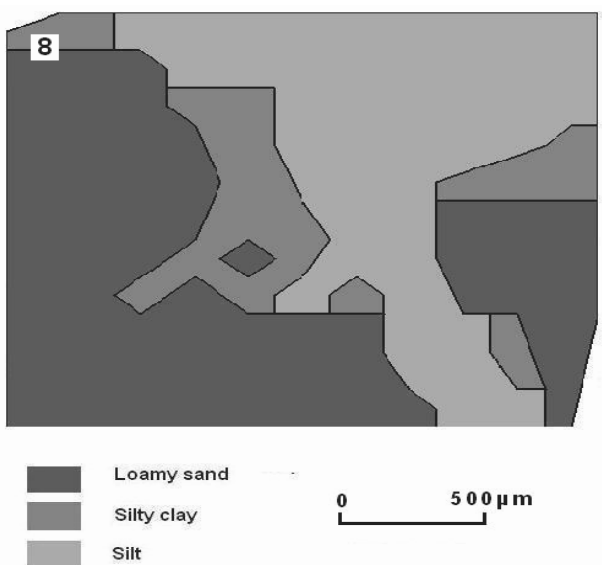
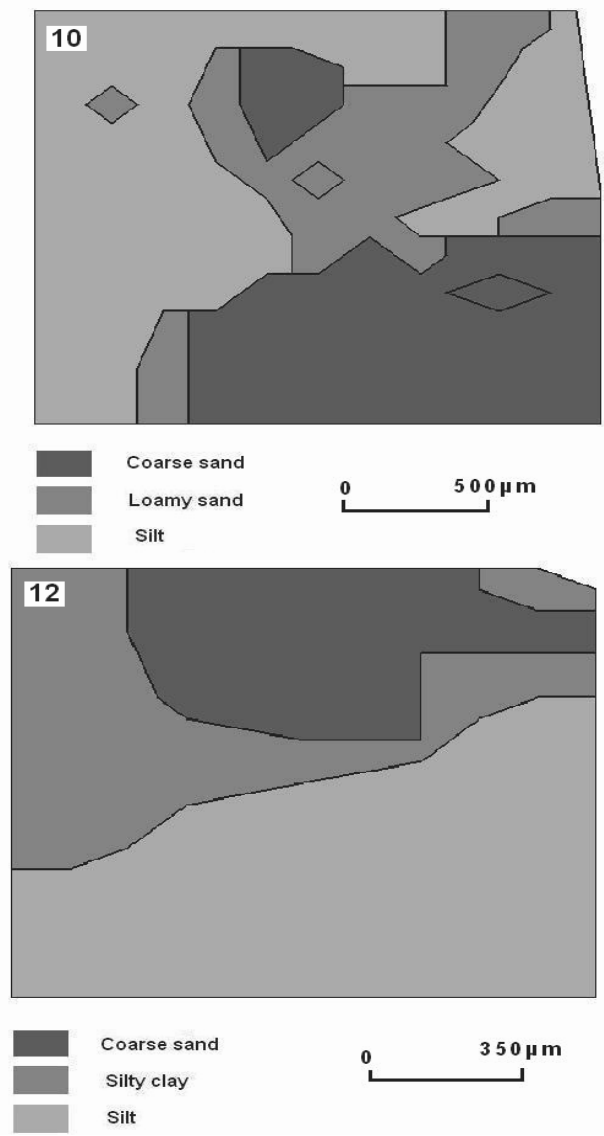

Silt

Figure 5. (Continued).

sediments. The grain size characters of these samples are the evidence of low process intensity during the deposition period.

\section{Conclusion}

Digital imaging of the microstructure of sediment layers is not a new experiment in sedimentological researches. In this study, the authors attempted microstructure mapping by using reflectance quality in greyscale images which is influenced by physical parameters like grain size, colour and grain structure. The main merit of the method is its simplicity. The image processing and slicing operation is brief and level of visibility is very high. The final output of microstructure map has a thematic format which is helpful to interpret depositional patterns easily. The microstructures of the tested samples show that the coarser depositions have more complex microfabric pattern than the finer depositions which indicates numbers of rapid fluctuations of deposition environment within a short duration in the present study area. 
Besides that this study also shows that although the present result is satisfactory, there are some demerits which are needed to be removed in future. One big demerit of this method is fixing a standard DN value range for a particular deposition type. It is an observed fact that under the same light and camera distance DN values of same minerals varies from one sample to another sample with the fractional change of grain sizes. Sometimes two or three different minerals/sediment types in a sample are represented by almost same DN value due to the similarity of some physical properties. It creates a genuine problem for classifying the DN groups perfectly and microfabric analysis by density slicing method in ' 8 bit' radiometry. For example, in the present study, it has been found that some light coloured (whitish) silt have very high DN values (from 175 extended up to 210) because of their colour and smooth surface which are almost very close to micaceous materials (196-255). Sometimes those two completely different types of compositions are fitted in the same DN group. The overlapping DN values of silt and micaceous are identified within 196 to 210 . To solve this problem manual observation and correction of mapping can be done. Editing of DN number by manual observation also can be done to overcome this problem. Instead of these problems it can be said that microstructure study by digital imaging can be a very handful tool for the geo-scientific assessment because it can prepare more prominent and perfect microstructure maps if the initial problems are solved carefully.

\section{References}

Alam M, Alam M M, Curray J R, Chowdhury M L R and Gani M R 2003 An overview of the sedimentary geology of the Bengal Basin in relation to the regional tectonic framework and basin-fill history; Sedim. Geol. 155 179-208.

Bagli S and Soille P 2003 Morphological automatic extraction of Pan-European coastline from Landsat ETM + images; International Symposium on GIS and Computer Cartography for Coastal Zone Management, October 2003, Genova.

Bale H D and Schmidt P W 1984 Small-angle X-ray scattering investigation of submicroscopic porosity with fractal properties; Phys. Rev. Lett. 53 596-599.

Bera S 1996 Remarks on Paleoenvironment from the Trace Fossil from Subsurface and Outcrop Tertiary-Quaternary Sediments of the Western Part of Bengal Basin, India; J. Geography and Environment 1 1-15.

Brewer R 1976 Fabric and mineral analysis of soils; Huntingdon, New York, Krieger.

Bryant R G and Davidson D A 1996 The use of image analysis in the micromorphological study of old cultivated soils: An evaluation based on a case study from the island of Papa Stour, Shetland; J. Archaeol. Sci. 23 811-822.

Cashman S M, Baldwin J N, Cashman K V, Swanson K and Crawford R 2007 Microstructures developed by coseismic and aseismic faulting in near-surface sediments, San Andreas Fault; Geology 35 611-614.

Chalabi A, Mohd-Lokman H, Mohd-Suffian I, Karamali K, Karthigeyan V and Masita M 2006 Monitoring shoreline change using Ikonos image and aerial photographs: A case study of Kuala Terengganu area, Malaysia (ISPRS Midterm Symposium Proceeding, May 2006, Enschede).

Cooper M C 1998 The use of digital image analysis in the study of laminated sediments; J. Paleolimnology 19(1) $33-40$.

Cocquyt C and Israe Y 2004 A microtome for sectioning lake sediment cores at a very high resolution; J. Paleolimnology 32 301-304.

Dey S, Dutta S and Adak S B 2002 Holocene sea level change of West Bengal coast; Indian Geographical Journal 77(1) $7-20$.

Dey S 2002 Impact of sea level change upon landform development along Digha coastal tract and risk assessment by process efficiency process; Indian J. Geomorphol. 7 111-117.

Dey S, Debbarma C and Sarker P 2008 Microgeomorphic assessment in grayscale environment; Indian J. Landform System and Ecological Studies 31(1) 223-231.

Dey S, Ghosh S, Debbarma C and Sarker P 2009 Some observation of regional evidences of Tertiary-Quaternary geo-dymanics in a paleo-coastal of Bengal basin, India; Russian Geology and Geophysics; Elsevier 50(11) in press.

Frazier P S and Page K J 2000 Water body detection and delineation with Landsat TM data; Photogrammetric Engineering and Remote Sensing 66(12) 147-167.

Hansen J P and Skjeltrop A P 1988 Fractal pore space and rock permeability implications; Phys. Rev. B 38 2635-2638.

Hazra S, Ghosh T, Baksi A and Ray N 2001 Sea level change: It's impact on West Bengal Coast; Indian J. Geography and Environment 6 25-37.

Katz A J and Thompson A H 1985 Fractal sandstone pores: Implications for conductivity and pore formation; Phys. Rev. Lett. 54 1325-1328.

Jacquin C G and Adler P M 1987 Geometry of porous geological structures; Transport in Porous Media 2 571-596.

Lachniet M S, Larson G J, Strasser J C, Eveason E B and Alley R B 1999 Microstructures of glacigienic sedimentflow deposits, Matanuska, Glacier, Alaska; Geol. Soc. Amer. Spec. Paper 337 45-57.

Lachniet M S, Larson G J, Lawson D E, Evenson E B and Alley R B 2001 Microstructures of sediment flow deposits and subglacial sediments: A comparison; Boreas 30(3) $254-262$

Mamtani M, Mukherji A and Chaudhuri A K 2007 Microstructure in banded iron formation (Gua Mine, India); Geological Magazine 144(2) 271-287.

Marfai M A, Almohammad H, Dey S, Susanto B and King L 2008 Coastal dynamic and shoreline mapping: Multisources spatial data analysis in Semarang Indonesia; Environ. Monit. Assess. 142 297-308.

Marfai M A 2003 Monitoring of the coastal zone dynamics by means of multi-temporal Landsat TM (Annual scientific meeting XII, Indonesian Remote Sensing Society, July 2003 Bandung).

Menzies J and Maltman A J 1992 Microstructures in diamictons - Evidence of subglacial bed conditions; Geomorphology 6 27-40.

Niyogi D 1970 Geological background of beach erosion of Digha, West Bengal; Bulletin, Geology Mining and Metallurgical Society of India $\mathbf{4 3}$ 1-36.

Pal A K 2002 Coastal Geomorphology and Environment (Kolkata, India: ACB Publications) 58 pp. 
Radlinski A P, Hinde A L, Rauch H, Hainbuchner M, Baron M, Mastalerz M, Ioannidis M and Thiyagarajan P 2005 The microstructure of rocks and small-angle and ultra-small-angle neutron scattering: The coming of age of a new technique; Geophys. Res. Abstracts 7 03865, SRef-ID: 1607-7962/gra/EGU05-A-03865.

Rohrig R and Scharf B W 2006 An alternative embedding method for thin section preparation of lake sediments; J. Paleolimnology 35 207-209.

Uddin A and Lundberg N 1998 Cenozoic history of the Himalayan-Bengal system: Sand composition in the Bengal basin, Bangladesh; Geol. Soc. Amer. Bull. 110 497-511.

Uddin A and Lundberg N 2004 Miocene sedimentation and subsidence during continent-continent collision, Bengal basin, Bangladesh; Sedim. Geol. 164 131-146.

Umitsu M 1987 Late quaternary sedimentary environment and landform evolution in the Bengal lowland; Geographical Review of Japan $60164-178$ pp.

van der Meer J J M 1987 Micromorphology of glacial sediments as a tool in distinguishing genetic varieties of till; Geol. Surv. Finland, Spec. Paper 3 77-89. van der Meer J J M and Laban C 1990 Micromorphology of some North Sea till samples, a pilot study; J. Quat. Sci. 5 95-101.

van der Meer J J M 1993 Microscopic evidence of subglacial deformation; Quat. Sci. Rev. 12 553-587.

van der Meer J J M 1996 Micromorphology; In: Glacial environments (ed.) Menzies J; Oxford, ButterworthHeinmann 2 335-355.

Vernon R H 2004 A Practical Guide to Rock Microstructure, Cambridge University Press, UK.

Whithe K and El Asmar H M 1999 Monitoring changing position of coastline using thematic mapper imagery, An example from the Nile Delta; Geomorphology 29(1-2) 93-105.

Wong P-Z, Howard J and Lin J-S 1986 Surface roughening and the fractal nature of rocks; Phys. Rev. Lett. $\mathbf{5 7}$ 637-640.

Yanli T 2002 The application of GIS and RS for coastline change detection and risk assessment to enhanced sea level rise; M.Sc Dissertation, Institute of Geoinformation Science and Earth Observation, ITC, Enschede. 